\title{
HABITAT SELECTION BY GREATER SAGE-GROUSE DURING WINTER IN SOUTHEASTERN OREGON
}

\author{
Christian A. Hagen ${ }^{1}$, Mitchell J. Willis², Elizabeth M. Glenn³ ${ }^{3}$ and Robert G. Anthony ${ }^{4}$
}

\begin{abstract}
The distribution and geographic range of Greater Sage-Grouse (Centrocercus urophasianus) have been reduced by 56\% since European settlement. Although loss and fragmentation of sagebrush (Artemisia spp.) habitats have been cited as the primary causes for the decline of the species, degradation of existing habitat also has been considered an important factor. Guidelines for protection and management of breeding and winter habitat have been developed for land managers, but winter habitat use has not been thoroughly described throughout the species' range, particularly for the western portion of its range in Oregon. We examined vegetation-type selection and use by Greater Sage-Grouse during winter (Nov-Feb) at 3 study areas in southeastern Oregon (1989-1992). Elevation gradients and vegetative communities differed among these 3 areas. Our objective was to examine the geographic variation in the selection and use of various vegetation types during winter, when sage-grouse distributions may be most restricted. We described differences in vegetation structure at the microhabitat scale among 3 areas and differences in vegetation-type selection at the macrohabitat scale. We found that the use of mixed sagebrush (basin big sagebrush [Artemisia tridentata tridentata]) and other shrubby vegetation types by sage-grouse was greater than expected at all 3 study areas. At the low- and high-elevation study areas, low sagebrush (Artemisia longiloba) vegetation types were selected more often than expected at random, which was contrary to our original hypotheses. Basin big sagebrush vegetation types were used in proportion to their availability at the 2 low-elevation study areas, and big sagebrush steppe was used less than available (avoided) at the low-elevation areas; these results were contrary to our original predictions. Such differences in selection among the study areas in southeastern Oregon create additional challenges for land managers, who are charged with managing habitats for sage-grouse use during autumn and winter in this portion of the species' geographic range.
\end{abstract}

RESUMEN.—La distribución y la extensión geográfica del urogallo de las artemisas (Centrocercus urophasianus) se ha reducido en un 56\% desde la colonización por los europeos. A pesar de que la pérdida y fragmentación de los hábitats de artemisas (Artemisia spp.) se han citado como las causas principales de la reducción de la especie, también se ha considerado como un factor importante la degradación de los hábitats existentes. Se han desarrollado directrices para los encargados de las tierras con la finalidad de mejorar la protección y el control de los hábitats reproductivos y de invierno; sin embargo, el uso de los hábitats de invierno no se ha descrito exhaustivamente a lo largo de la distribución geográfica de la especie, particularmente en la región occidente de su distribución en Oregón. Examinamos el tipo de vegetación seleccionado y usado por el urogallo de las artemisas durante el invierno (noviembre-febrero) en tres áreas de estudio al sureste de Oregón (1989-1992). Los gradientes de elevación y las comunidades vegetales fueron diferentes entre estas 3 áreas. Nuestro objetivo fue examinar la variación geográfica en la selección y el uso de varios tipos de vegetación durante el invierno, cuando las distribuciones del urogallo de las artemisas podrían estar más restringidas. Describimos diferencias en la estructura de la vegetación en el microhábitat de 3 áreas, así como también diferencias en la selección del tipo de vegetación a la escala de macrohábitat. Encontramos que el uso que le da el urogallo de las artemisas a la Artemisia tridentata mixta y a otros tipos de vegetación arbustiva fue mucho mayor a lo esperado en las 3 áreas estudiadas. En las áreas estudiadas de elevación baja y alta, el tipo de vegetación conformado por A. longiloba se seleccionó aleatoriamente más a menudo de lo esperado, contrario a nuestra hipótesis inicial. En las 2 áreas estudiadas de elevación baja, el tipo de vegetación de A. tridentata se usó en proporción a su disponibilidad; también en las áreas de elevación baja, la estepa de artemisa se usó menos de lo que correspondía a su disponibilidad (se evitó). Estos resultados representan lo opuesto a nuestras predicciones originales. Estas diferencias en la selección entre las áreas estudiadas al sureste de Oregón crea retos adicionales para los administradores de las tierras, quienes tienen el cargo de regular los hábitats para el uso del urogallo de las artemisas durante el otoño y el invierno en esta porción de la distribución geográfica de la especie.

The distribution and geographic range of Greater Sage-Grouse (Centrocercus urophasianus) have been reduced by $56 \%$ since European settlement of western North America (Connelly and Braun 1997, Schroeder et al. 2004). Although loss and fragmentation of sagebrush (Artemisia spp.) habitats have been cited as the primary causes for the decline of the species, degradation

\footnotetext{
1'Oregon Department of Fish and Wildlife, 61374 Parrell Road, Bend, OR 97702. E-mail: centrocercus@gmail.com

2 Eastern Oregon Agricultural Research Station, 67826-A Hwy. 205, Hines, OR 97720.

${ }^{3}$ Department of Fisheries and Wildlife, 104 Nash Hall, Oregon State University, Corvallis, OR 97331

${ }^{4}$ Oregon Cooperative Fish \& Wildlife Research, Department of Fisheries and Wildlife, 104 Nash Hall, Oregon State University, Corvallis, OR 97331
} 
of existing habitat also has been considered an important factor (Braun 1998). Guidelines for protection and management of breeding and winter habitat have been provided to land managers (Connelly et al. 2000); however, habitat use during winter has not been thoroughly described throughout the species' range (Hagen et al. 2007), particularly for the western portion of the range of Greater Sage-Grouse in Oregon.

Most observations of radio-marked sagegrouse during winter in Montana occurred in basin big sagebrush (Artemisia tridentata tridentata) habitats with $>20 \%$ canopy cover (Eng and Schladweiler 1972). However, during 3 winters in southeastern Idaho, sage-grouse used sagebrush habitats that had average canopy coverage of 15\% and height of $46 \mathrm{~cm}$ (Robertson 1991). The species also selected areas with greater canopy cover of Wyoming big sagebrush (Artemisia tridentata wyomingensis) in stands containing taller shrubs than those at random sites (Robertson 1991). More recently, the importance of low sagebrush (Artemisia longiloba; Freese 2009) and black sagebrush (Artemisia nova; Thacker 2010) as winter habitat has been documented. Availability of winter habitat can be a limiting factor to survival rates and population growth of sage-grouse (Moynahan et al. 2006, Anthony and Willis 2009). Because winter survival is typically high, periodic or catastrophic winter mortality events may be one of the major factors regulating sage-grouse population growth. Thus, understanding regional variation in habitat selection and use during winter is critical to providing adequate management guidelines and conservation measures.

During winter in some portions of their geographic range, sage-grouse often occupy big sagebrush habitats on low-elevation sites with deeper soils (Beck 1977, Hupp and Braun 1989, Battazzo 2007). Alternatively, higherelevation sites dominated by low (or little) sagebrush or black sagebrush may be used if these sites have been cleared of snow by prevailing winds (Hanf et al. 1994, Freese 2009, Thacker 2010). Sage-grouse often exhibit highly selective foraging behavior, as illustrated by their selection of Wyoming big sagebrush leaves (which have fewer terpenoids and greater protein content than leaves of other sages) during winter in Colorado (Remington and Braun 1985) or their selection of black sagebrush in Utah (Thacker 2010). In the past, ecological sites favoring basin big sagebrush (A. t. tridentata) have been targeted for conversion to agricultural uses (Swenson et al. 1987), in part because of the deeper soils encountered at these sites. More recently, these low-elevation areas have been invaded by exotic annual grasses and are at increased risk of the type of conversion that results from wildfire (Wisdom et al. 2002).

We examined habitat selection and use by sage-grouse during winter (Nov-Feb) at 3 study areas in southeastern Oregon (1989-1992). Our objectives were to (1) characterize the geographic variation in vegetation structure at sites used by sage-grouse and (2) quantify the selection and use of various vegetation types during winter, when sage-grouse distributions may be most restricted by weather and elevation. Specifically, we predicted that basin big sagebrush vegetation types would be selected over low sagebrush at the mid- and low-elevation study areas, and that low sagebrush would be selected more frequently than big sagebrush types at the high-elevation study area (Hart Mountain National Antelope Refuge [HMNAR]).

\section{Methods \\ Study Areas}

We monitored Greater Sage-Grouse populations in Malheur (Jordan Valley), Harney (Jack Creek), and Lake counties (HMNAR), Oregon, during the winters of 1989-1992. The 3 study areas were selected because they were representative of the elevational gradient of sagebrush vegetation communities in southeastern Oregon. Summers are generally hot and dry. Most precipitation occurs as snow during winter, with some rain in April and May.

The Jordan Valley study area was lowest in elevation (915-1675 m). Vegetation types found on the area were Wyoming big sagebrush, early flowering or low sagebrush, mosaics of sagebrush and rabbitbrush (Chrysothamnus spp.), and low sagebrush with horsebrush (Tetradymia canescens) and/or spiny hopsage (Grayia spinosa). Common grasses recorded were Sandberg bluegrass (Poa secunda), bluebunch wheatgrass (Pseudoroegneria spicata), cheatgrass (Bromus tectorum), crested wheatgrass (Agropyron cristatum), basin wild rye (Leymus cinereus), and squirreltail (Elymus elymoides). The vegetation was similar to the other 2 areas, except that approximately $25 \%$ of the area was composed of crested wheatgrass plantings established in the 1960s as part of the Bureau of Land 
Management's Vale Rangeland Rehabilitation Program (Heady and Bartolome 1977). Longterm climate (1939-2010) conditions included average maximum temperatures ranging from 3.3 to $31.8^{\circ} \mathrm{C}$ and average minimum temperatures of -9.4 to $8.8^{\circ} \mathrm{C}$. Annual average precipitation was $29 \mathrm{~cm}$ during this period. Long-term winter (Nov-Feb) minimum temperature averaged $-7.4{ }^{\circ} \mathrm{C}$, and snowfall averaged $11.4 \mathrm{~cm}$. Minimum temperatures for November-February during our study averaged $-6.8^{\circ} \mathrm{C}$ (range -16.9 to $0.6{ }^{\circ} \mathrm{C}$ ), and precipitation totaled 2.9 , 3.0 , and $2.2 \mathrm{~cm}$ for the 3 respective winters.

The Jack Creek study area was intermediate in elevation (1500-1700 m) and was typical of Wyoming big sagebrush plant communities in southeastern Oregon. The vegetation was similar to HMNAR, except mountain big sagebrush (Artemisia tridentata vaseyana) and associated shrubs and grasses were not found there; basin big sagebrush was interspersed throughout the area. The area, most of which is managed by the Bureau of Land Management (BLM), is located $64 \mathrm{~km}$ south of Burns, Harney County, Oregon. Long-term climate (1939-2010) conditions included average maximum temperatures ranging from 0.5 to $30.9{ }^{\circ} \mathrm{C}$ and average minimum temperatures ranging from -12.3 to $7.3^{\circ} \mathrm{C}$. Annual average precipitation was $23 \mathrm{~cm}$ during the study period. Long-term winter (Nov-Feb) minimum temperature averaged $-9.2{ }^{\circ} \mathrm{C}$, and annual snowfall was $17.1 \mathrm{~cm}$. Minimum temperatures for November-February during our study averaged $-8.0^{\circ} \mathrm{C}$ (range -19.5 to $-0.7^{\circ} \mathrm{C}$ ), and precipitation totaled 3.6, 4.4, and $6.5 \mathrm{~cm}$ in the 3 winters, respectively.

HMNAR was the highest in elevation (1525$2435 \mathrm{~m}$ ) and had the most productive and diverse plant communities, which were dominated by mountain big sagebrush, Wyoming big sagebrush, low sagebrush, antelope bitterbrush (Purshia tridentata), and rabbitbrush (Chrysothamnus sp.) with bluebunch wheatgrass, rough fescue (Festuca campestris), Idaho fescue (Festuca idahoensis), Sandberg bluegrass, squirreltail, needle-and-thread (Hesperostipa comata), and occasional cheatgrass. The area is located $72 \mathrm{~km}$ northeast of Lakeview, Lake County, Oregon, and is managed by the U.S. Fish and Wildlife Service as part of the refuge system. Long-term climate (1939-2010) conditions included average maximum temperatures ranging from 3.8 to $27.4{ }^{\circ} \mathrm{C}$ and average minimum temperatures ranging from -7.6 to $6.7^{\circ} \mathrm{C}$.
Annual average precipitation was $3.0 \mathrm{~cm}$ during this period. Long-term winter (Nov-Feb) minimum temperature averaged $-6.3{ }^{\circ} \mathrm{C}$ and snowfall averaged $17.8 \mathrm{~cm}$. Minimum temperatures for November-February during our study averaged $-6.2^{\circ} \mathrm{C}$ (range -18.2 to $-1.9{ }^{\circ} \mathrm{C}$ ), and precipitation totaled $4.6,3.6$, and $7.8 \mathrm{~cm}$ for the 3 respective winters.

\section{Field Methods}

Using spotlighting, net guns, and rocket nets, we captured 135 adult $(>1.5$ years old) female sage-grouse during the spring and summer of each year at areas of concentrated use and areas near leks (Giesen et al. 1982). Capture locations were selected opportunistically within each of the study areas to maximize capture efficiency. Most of the captured birds at HMNAR and Jack Creek were spring captures at leks to monitor breeding ecology of those populations (see Gregg et al. 1993, Drut et al. 1994). Captures of grouse near Jordan Valley focused on agricultural fields from August to October where large concentrations occurred. Radio-transmitters weighing approximately $28 \mathrm{~g}$ (Telemetry Systems Inc., Mequon, WI) were mounted on a reinforced vinyl poncho and placed over the neck of each female at capture (Amstrup 1980). Using aerial and ground telemetry at all 3 study areas, attempts were made to locate females at least every 2 weeks from early November to the end of February, when breeding congregations began forming and when habitat use may have been affected by the female's biological drive to seek nesting sites as the breeding season commenced. Radio-locations from ground telemetry were obtained by making visual observation of, or flushing, radio-marked grouse. We used aerial telemetry when birds went missing or when road access was limited. Aerial locations were verified on the ground as soon as practicable. Each location was referenced using LORAN units. The number of birds monitored each year varied; however, attempts were made to maintain a minimum of 20 marked individuals on each study area at all times by periodically capturing and attaching radio-transmitters to additional females.

Fine-scale characteristics of vegetation and topography were measured at each radiotelemetry location and at random encounters with sage-grouse while telemetry was being conducted. These samples were referred to as microhabitat characteristics and differed from 
the GIS information at the macrohabitat scale. At each grouse location we characterized the general vegetation type as 1 of 4 types (i.e., big sagebrush, low sagebrush, mosiac [codominance of low and big sagebrush], and low sagebrush mixed with saltbrush [Atriplex canescens]). Canopy cover was estimated using the lineintercept method (Canfield 1941). We used 3 line transects $(30 \mathrm{~m})$ that were aligned perpendicular to the slope; shrub height and snowdepth were measured along the line transects to the nearest $\mathrm{cm}$ and averaged over the transects. Slope and aspect were recorded using a compass and clinometer. We estimated means (and SEs) and compared differences among study areas of each variable using 2-way ANOVAs. We examined the significance of the interaction of study area $\times$ vegetation type using multiple pairwise comparisons.

We used radio-telemetry location data for the GIS analyses that we collected from the Jordan Valley ( $n=286$ locations) study area for 3 years, and the HMNAR ( $n=179$ locations) and Jack Creek ( $n=139$ locations) areas for 2 years. We analyzed results based on 3 years of data for Jordan Valley and 2 years of data for the 2 other areas. Proportional use of available habitats did not differ significantly between the winter of 1989-1990 and the last 2 winters combined (when data from all study areas were collected) for the Jordan Valley area $\left(\chi^{2}=12.74\right.$, $\mathrm{df}=11, P=0.311)$. Thus, to maximize sample sizes, we pooled Jordan Valley samples from all 3 winters for the analysis.

\section{Vegetation-type Mapping}

We described the availability of vegetation types on the 3 study areas at the macrohabitat scale using SAGEMAP: Current Distribution of Sagebrush and Associated Vegetation in the Columbia Basin and Southwestern Regions (U.S. Geological Survey, Forest and Rangeland Ecosystem Science Center, Snake River Field Station, Boise, ID 83706, Version 1.0). This regional dataset was produced using a decision tree classifier and other techniques to model landcover. Multiseason satellite imagery (Landsat $\mathrm{ETM}+$, 1999-2003) and digital elevation model datasets (e.g., elevation, landform, aspect, etc.) were utilized to derive rule sets for the various landcover classes. Eleven mapping areas, each characterized by similar ecological and spectral characteristics, were modeled independently of one another. The full regional map contained 126 land-cover classes and had a minimum mapping unit of approximately 0.4 ha. The area encompassing our 3 study areas contained 53 land-cover classes. To analyze habitat selection, we combined the original Shrubmap categories into 12 vegetation types representing habitat types known to be used by sage-grouse (Table 1).

Shrubmap is available online (http://sagemap .wr.usgs.gov/ShrubMap.aspx) as a digital raster map with a 30-m grid cell resolution. Model validation was performed by testing model accuracy using a portion (20\%) of the sample data that was withheld from the modeling process. Overall map accuracy (53 land-cover classes) was $89 \%$, and the overall misclassification rate was $11 \%$. When we combined land-cover classes into 12 categories, overall map accuracy increased to $90 \%$ with an overall misclassification rate of $10 \%$.

\section{Statistical Analysis}

We used logistic regression to estimate habitat selection at the macrohabitat scale as the odds ratio (Hosmer and Lemeshow 1989:40) of use versus availability among vegetation types at the 3 study areas. Our binary response variable included radiotelemetry locations of sage-grouse (1) and random points (800 per study area) generated within the area estimated to be available to the radio-marked animals at each study area (0). We delineated the area available to sage-grouse by buffering the telemetry locations for each study area by $1.6 \mathrm{~km}$, the mean daily movement $(n=717$ consecutive points, $\bar{x}=1.63 \mathrm{~km}, \mathrm{SE}=0.127$ ) of sagegrouse during our study. We used odds ratios as a measure of selection of a given vegetation type relative to a reference type (Rosenberg and McKelvey 1999), which is the same as a resource selection function (Manly et al. 2002). For all 3 study areas, we used an "other" vegetation type as our reference, because this category was composed of the vegetation types that were not typically used by sage-grouse (Table 1). To estimate the predictive power of our models, we calculated McFadden's adjusted $R^{2}$. This statistic behaves similarly to the $\mathrm{R}^{2}$ for linear models, is based on the maximum likelihood theory, and is scaled to account for the discrete independent variables (Shtatland et al. 2000). We evaluated goodness-of-fit of our models using the Hosmer-Lemeshow test (Hosmer and Lemeshow 1989). 


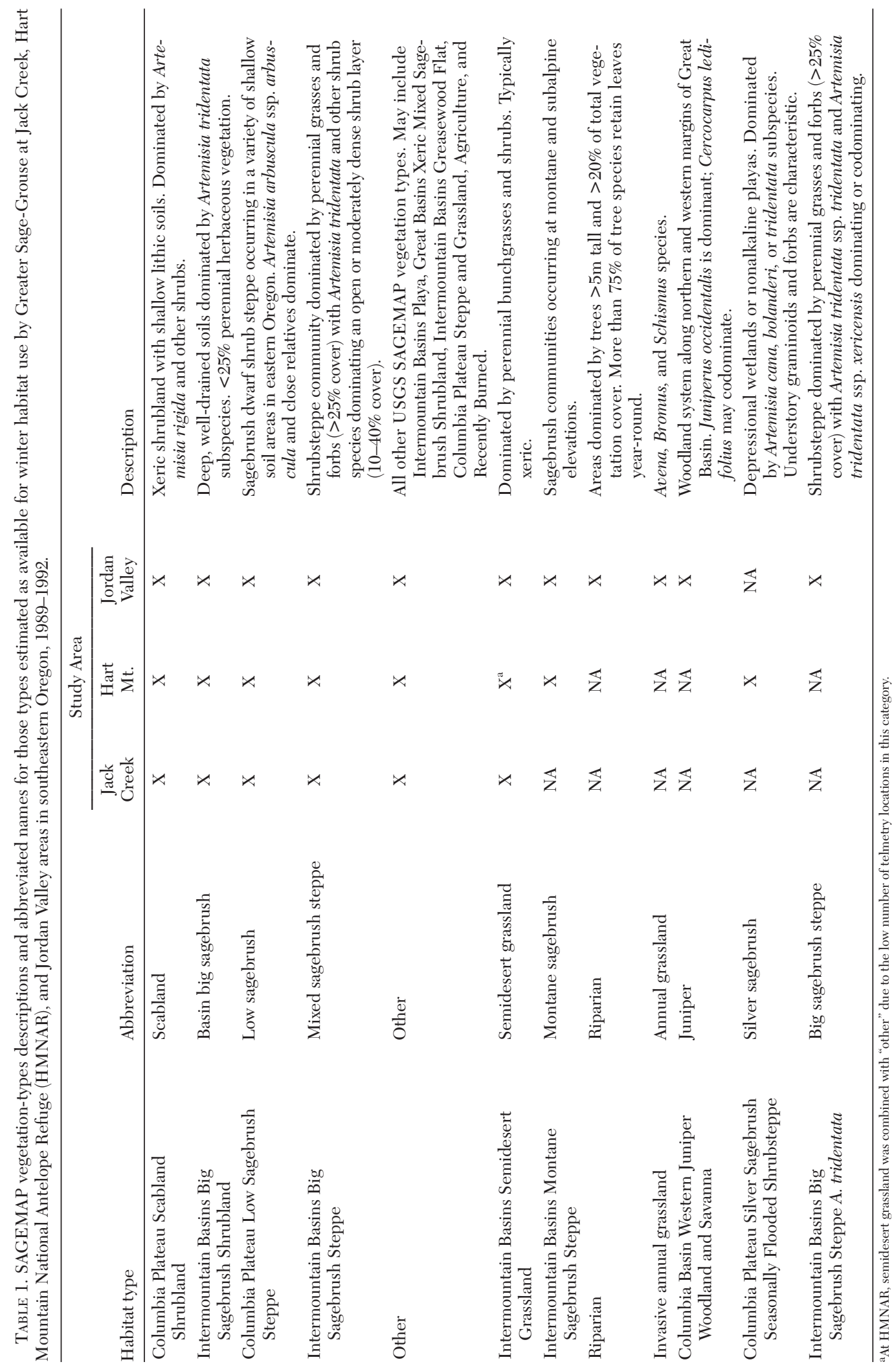


TABLE 2. Summary statistics for microscale variables measured at 4 vegetation types that occurred at 3 study areas in southeastern Oregon, 1989-1992. Different letters between columns indicate statistical significance $(P<0.05)$ using Holm-Sidak multiple comparisons tests.

\begin{tabular}{|c|c|c|c|c|c|c|c|c|c|c|c|c|}
\hline \multirow[b]{2}{*}{ Variable / veg. type } & \multicolumn{4}{|c|}{ Jordan Valley } & \multicolumn{4}{|c|}{ Jack Creek } & \multicolumn{4}{|c|}{ HMNAR } \\
\hline & $n^{\mathrm{a}}$ & $\bar{x}$ & $\mathrm{SE}$ & & $n$ & $\bar{x}$ & $\mathrm{SE}$ & & $n$ & $\bar{x}$ & SE & \\
\hline \multicolumn{13}{|l|}{ Shrub cover $(\%)$} \\
\hline Low sagebrush & 134 & 4.63 & 0.26 & $\mathrm{~A}$ & 85 & 8.54 & 0.32 & B & 208 & 7.24 & 0.20 & $\mathrm{C}, \mathrm{D}$ \\
\hline Big sagebrush & 49 & 4.87 & 0.42 & A & 43 & 10.60 & 0.45 & B & 3 & 11.33 & 1.70 & $\mathrm{C}, \mathrm{B}$ \\
\hline Mosaic sagebrush & 115 & 6.27 & 0.28 & $\mathrm{~A}$ & 113 & 8.78 & 0.27 & $\mathrm{~B}$ & 15 & 6.97 & 0.76 & A,B \\
\hline Low sage/saltbrush & 2 & 3.45 & 2.08 & A & 8 & 6.24 & 1.04 & A & 21 & 7.07 & 0.64 & $\mathrm{~A}$ \\
\hline \multicolumn{13}{|l|}{ Shrub height $(\mathrm{cm})$} \\
\hline Low sagebrush & & 30.08 & 0.89 & A & & 24.04 & 1.12 & B & & 27.81 & 0.71 & C,D \\
\hline Big sagebrush & & 51.76 & 1.47 & A & & 55.93 & 1.57 & A & & 49.00 & 5.94 & A \\
\hline Mosaic sagebrush & & 41.28 & 0.96 & $\mathrm{~A}$ & & 34.30 & 0.97 & B & & 30.13 & 2.66 & $\mathrm{C}, \mathrm{B}$ \\
\hline Low sage/saltbrush & & 33.50 & 7.28 & $\mathrm{~A}$ & & 27.13 & 3.64 & A & & 24.33 & 2.25 & $\mathrm{~A}$ \\
\hline \multicolumn{13}{|l|}{ Snow depth $(\mathrm{cm})$} \\
\hline Low sagebrush & & 1.86 & 0.28 & A & & 0.40 & 0.35 & B & & 0.70 & 0.22 & C,D \\
\hline Big sagebrush & & 5.04 & 0.46 & A & & 0.12 & 0.49 & $\mathrm{~B}$ & & 2.33 & 1.86 & A,B \\
\hline Mosaic sagebrush & & 1.77 & 0.30 & A & & 0.35 & 0.30 & A & & 0.20 & 0.83 & A,B \\
\hline Low sage/saltbrush & & 1.00 & 2.27 & A & & 0.25 & 1.14 & A & & 0.48 & 0.70 & A \\
\hline \multicolumn{13}{|l|}{ Aspect $\left({ }^{\circ}\right)^{\mathrm{b}}$} \\
\hline Low sagebrush & & 175 & 9 & & & 189 & 12 & & & 149 & 7 & \\
\hline Big sagebrush & & 214 & 16 & & & 186 & 17 & & & 142 & 58 & \\
\hline Mosaic sagebrush & & 170 & 10 & & & 235 & 10 & & & 136 & 28 & \\
\hline Low sage/saltbrush & & 162 & 71 & & & 170 & 38 & & & 145 & 23 & \\
\hline
\end{tabular}

aSample sizes are the same for all variables.

bNo statistical tests were used to compare differences in aspect; only means and standard errors are reported.

\section{Results}

Microhabitat characteristics of sites used by sage-grouse were summarized for each of the 4 vegetation types and compared among vegetation types in the 3 study areas (Table 2). Shrub cover around grouse locations was lower $\left(F_{6,784}=4.756, P<0.001\right)$ and shrub heights were taller $\left(F_{6,784}=5.119, P<0.001\right)$ at Jordan Valley use sites than at the other 2 study areas $(P<0.05$; Table 2$)$. Snow depth was greatest at Jordan Valley and least at Jack Creek, with HMNAR falling in between $\left(F_{6,784}=\right.$ $3.807, P<0.001)$. There was little variation in slope among vegetation types in the 3 study areas $\left(F_{6,784}=0.758, P=0.603\right)$ or among study areas $\left(F_{2,784}=2.573, P=0.077\right)$, where average slopes were $2.8 \%(\mathrm{SE}=0.39), 1.8 \%$ $(\mathrm{SE}=0.22)$, and $2.0 \%(\mathrm{SE}=0.35)$ at Jordan Valley, Jack Creek, and HMNAR, respectively. The aspect at which most use sites were located was south $\left(\bar{x}=180.2^{\circ}\right)$ at Jordan Valley, southwest $\left(\bar{x}=194.9^{\circ}\right)$ at Jack Creek, and southeast $\left(\bar{x}=142.9^{\circ}\right)$ at HMNAR.

The 3 study areas differed in the vegetation communities that were available and used by sage-grouse at the macrohabitat scale; thus, separate analyses were conducted for each area
(Fig. 1). Because of these differences in availability, there were also differences in the patterns of selection and avoidance of the different vegetation types (Table 3). Mixed sagebrush types and low sagebrush were used more than their availability, whereas big sagebrush habitats were used in proportion to their availability. Model fit was reasonable for all 3 study areas as indicated by the Hosmer-Lemeshow statistics $(P>0.99)$, and measure of overdispersion (deviance/df) was $<1$ (Table 3 ). The predictive power for the Jordan Valley model (McFadden's $\left.R^{2}=0.213\right)$ was greater than the predictive power for HMNAR and Jack Creek $\left(R^{2}<0.09\right)$.

At the Jordan Valley study area, we identified 11 vegetation types available to sagegrouse: the 5 most abundant included big sagebrush steppe (42\%), low sagebrush (16\%), riparian $(9 \%)$, “other" (9\%), and mixed sagebrush steppe (6\%; Fig. 1A). The logistic regression model for Jordan Valley indicated that sagegrouse used low sagebrush 2.1 times more often than the "other" vegetation type, mixed sagebrush steppe 3.8 times more often, annual grassland 1.9 times more often, and juniper 2.1 times more often (Table 3). Big sagebrush steppe was used 0.6 times less often than the "other" type, indicating that big sagebrush steppe was 

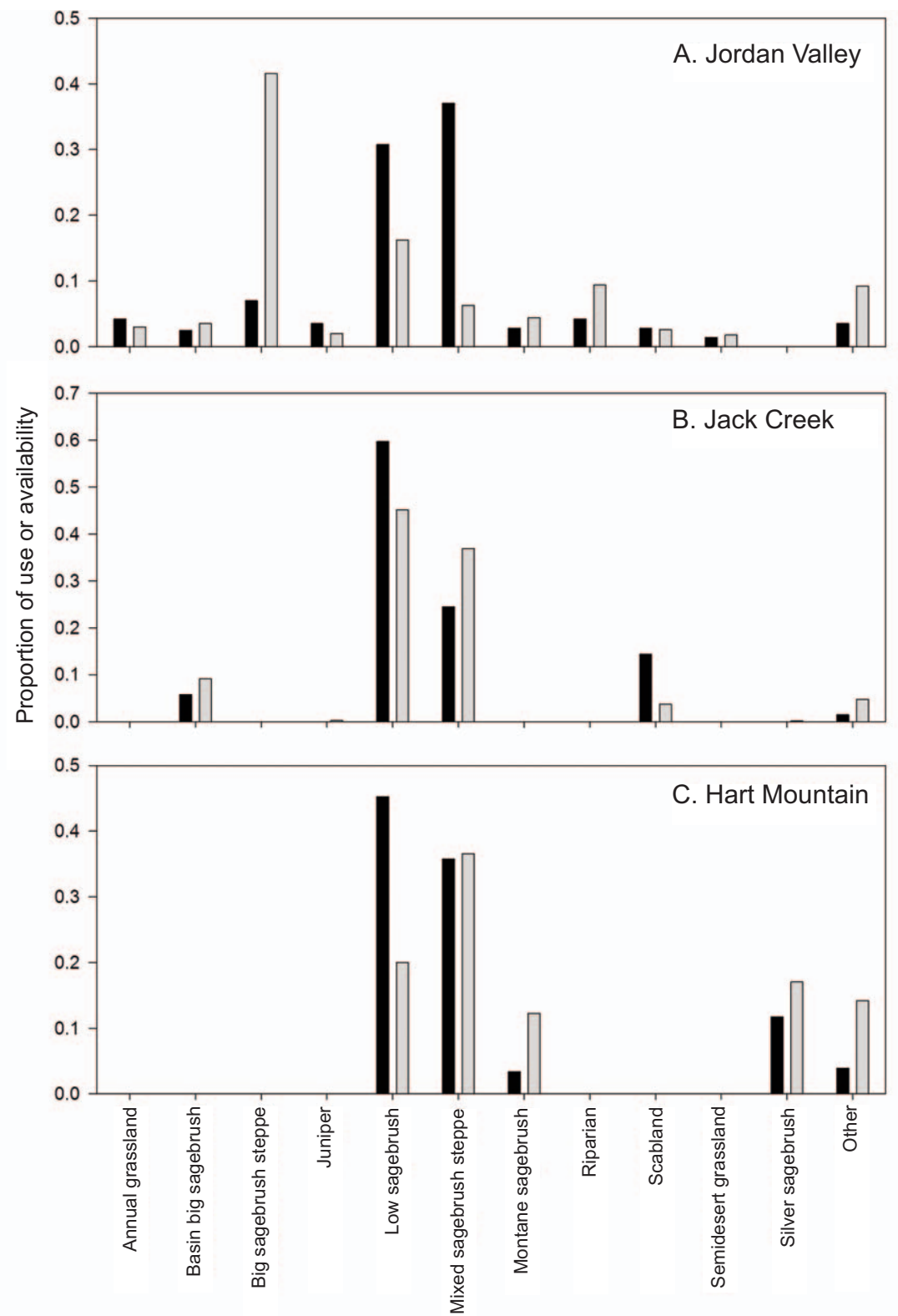

Fig 1. Proportions of vegetation types used by (black bars) and available to (gray bars) radio-marked Greater SageGrouse at Jordan Valley (A), Jack Creek (B), and Hart Mountain National Antelope Refuge (C) in southeastern Oregon, 1989-1992.

avoided. The remaining vegetation types were used in proportion to their availability.

At the Jack Creek study area, we identified 5 vegetation types that were available to sagegrouse: low sagebrush (45\%), mixed sagebrush steppe $(37 \%)$, basin big sagebrush (9\%), other $(5 \%)$, and scabland (4\%; Fig. 1B). For this area, telemetry locations and random points that occurred in semidesert grassland were classified as "other" because the number of points in this category was too low for the logistic regression model to converge. Our logistic regression model for Jack Creek indicated that grouse used scabland 3.5 times more often than the "other" type and mixed sagebrush 2.2 times more often than "other" type (Table 3). 
TABLE 3. Beta estimates, standard errors, and Wald $\chi^{2}$ values for covariates representing individual vegetation types in logistic regression models for habitat selection by Greater Sage-Grouse at 3 study areas in southeastern Oregon 1989-1992. Odds ratios for use of each vegetation type by sage-grouse at Jordan Valley, Jack Creek, and Hart Mountain National Antelope Refuge (HMNAR) study areas relative to the vegetation type "other."

\begin{tabular}{|c|c|c|c|c|c|c|}
\hline Area/effect & Estimate & $\mathrm{SE}$ & Wald & $P$ & Odds & Selection $^{\mathrm{a}}$ \\
\hline \multicolumn{7}{|c|}{ Jordan Valley (McFadden's $\left.\mathrm{R}^{2}=0.213\right)^{\mathrm{b}}$} \\
\hline Annual grassland & 0.621 & 0.234 & 6.676 & 0.01 & 1.860 & + \\
\hline Basin big sagebrush & 0.257 & 0.261 & 0.969 & 0.325 & 1.293 & o \\
\hline Big sagebrush steppe & -0.454 & 0.194 & 5.383 & 0.02 & 0.635 & - \\
\hline Juniper & 0.715 & 0.251 & 8.130 & 0.004 & 2.045 & + \\
\hline Low sagebrush & 0.757 & 0.173 & 19.202 & $<0.001$ & 2.131 & + \\
\hline Mixed sagebrush steppe & 1.322 & 0.178 & 55.016 & $<0.001$ & 3.751 & + \\
\hline Montane sagebrush & 0.210 & 0.250 & 0.704 & 0.401 & 1.233 & o \\
\hline Riparian & 0.033 & 0.221 & 0.022 & 0.882 & 1.033 & o \\
\hline Scabland & 0.473 & 0.257 & 3.369 & 0.066 & 1.604 & o \\
\hline Semidesert grassland & 0.310 & 0.319 & 0.943 & 0.331 & 1.363 & o \\
\hline \multicolumn{7}{|c|}{ Jack Creek (McFadden's $\left.\mathrm{R}^{2}=0.044\right)^{\mathrm{c}}$} \\
\hline Basin big sagebrush & 0.404 & 0.397 & 0.988 & 0.320 & 1.497 & o \\
\hline Mixed sagebrush steppe & 0.774 & 0.356 & 4.458 & 0.035 & 2.169 & + \\
\hline Low sagebrush & 0.429 & 0.362 & 1.327 & 0.249 & 1.535 & o \\
\hline Scabland & 1.254 & 0.381 & 10.270 & 0.001 & 3.503 & + \\
\hline \multicolumn{7}{|c|}{ HMNAR (Max. rescaled $\left.\mathrm{R}^{2}=0.087\right)^{\mathrm{d}}$} \\
\hline Low sagebrush & 1.184 & 0.199 & 33.470 & $<0.001$ & 3.269 & + \\
\hline Mixed sagebrush steppe & 0.848 & 0.199 & 17.050 & $<0.001$ & 2.334 & + \\
\hline Montane sagebrush & 0.130 & 0.278 & 0.209 & 0.647 & 1.138 & o \\
\hline Silver sagebrush & 0.590 & 0.220 & 6.836 & 0.009 & 1.803 & + \\
\hline
\end{tabular}

aHabitat selection for a given type is noted by "+", avoidance is noted by "-", and no selection or as expected at random is noted by "o."

bHosmer-Lemeshow statistic $=0.318, P=0.99$, overdispersion $(\mathrm{dev} / \mathrm{df})=0.850$

${ }^{\mathrm{c}}$ Hosmer-Lemeshow statistic $=0.114, P=0.99$, overdispersion $(\mathrm{dev} / \mathrm{df})=0.828$

${ }^{\mathrm{d}}$ Hosmer-Lemeshow statistic $=0.228, P=0.99$, overdispersion $(\mathrm{dev} / \mathrm{df})=0.878$

Low and basin big sagebrush were used in proportion to their availability (odds ratios not different from 1).

We identified 5 vegetation types available to sage-grouse at HMNAR: mixed sagebrush steppe $(37 \%)$, low sagebrush $(20 \%)$, silver sagebrush (17\%), "other" (14\%), and montane sagebrush (12\%; Fig.1C). For this area, telemetry locations and random points that occurred in semidesert grassland were classified as "other" because the number of points in this category was too low for the logistic regression model to converge. The logistic regression model for HMNAR indicated that sage-grouse used low sagebrush 3.3 times more often than the "other" type, mixed sagebrush steppe 2.3 times more often, and silver sagebrush 1.8 times more often (Table 3). The odds ratio for montane sagebrush did not differ from 1.0, indicating that vegetation type was used in proportion to its availability.

\section{Discussion}

Our study identified the potential importance of low sagebrush to sage-grouse during winter. Locations of sage-grouse habitats during winter were on flat-to-gentle, southerly exposed topography at the microhabitat scale. Contrary to our predictions, mixed sagebrush and low sagebrush vegetation types were more likely to be selected than big sagebrush or montane sagebrush vegetation types at all 3 study areas. Although, we did not explicitly identify thresholds of sagebrush cover, availability of sagebrush within a $1.6-\mathrm{km}$ radius of sage-grouse locations ranged between $72 \%$ and $91 \%$ of our study areas. Our findings support the growing evidence suggesting that $70 \%-80 \%$ of a landscape needs to be composed of sagebrush cover to have a high likelihood of use and population persistence by sage-grouse (Doherty et al. 2008, Knick and Hanser 2011).

Contrary to most studies of habitat use by sage-grouse during winter (Eng and Schladweiler 1972, Beck 1977, Hupp and Braun 1989, Robertson 1991, Battazzo 2007), we found that sage-grouse use of low and mixed sagebrush habitats was high on all 3 study areas, and sage-grouse used these habitats equal to or in higher proportion than their availability (Fig. 1). The low sagebrush habitat type only occupied $18 \%$ of the Jordan Valley area, but was used by sage-grouse at about twice that rate. In addition, 
scablands dominated by scabland sagebrush types (e.g., Artemisia rigida) were selected by sage-grouse on the Jack Creek study area, and silver sagebrush was selected at HMNAR. The mixed sagebrush vegetation type is a codominant of taller-stature sagebrush subspecies (e.g., basin, Wyoming, and mountain big sagebrush), and other shrub species, such as antelope bitterbrush or four-wing saltbush, occur in this type. The vegetation structure in these mixed stands was more consistent with ecological sites identified as important wintering areas elsewhere across the range (Eng and Schladweiler 1972, Beck 1977, Hupp and Braun 1989, Robertson 1991, Battazzo 2007). Although shorter sagebrush types (low, scabland, and silver sagebrush) may not provide adequate cover $(<10 \%$ canopy cover, $<30 \mathrm{~cm}$ in height in our study) during severe winter weather or for concealment from predators, they appear to serve as potentially important foraging areas (Freese 2009, Thacker 2010). Low, black, and silver sagebrush as well as prairie sagewort (Artemisia frigida) are consumed in many areas depending on their availability (Dalke et al. 1963, Beck 1977, Wallestad et al. 1975, Freese 2009, Thacker 2010). Although we did not investigate the diets of sage-grouse on our study areas, we suspect that sage-grouse were using the low sagebrush vegetation types as foraging and loafing areas on all 3 study areas.

Use and availability of the other vegetation types that are not mentioned above were generally low $(<10 \%)$ on our study areas, so we cannot make any definitive statements about their importance as sage-grouse habitat during winter. For example, results of our logistic regression suggested that annual grasslands (i.e., those dominated by Bromus spp.) were selected on the Jordan Valley study area, yet this type comprised $<5 \%$ of the area and was used $<5 \%$ of time. Similarly, semidesert grasslands dominated by perennial bunchgrasses and juniper (Juniperus occidentalis) woodlands comprised $<5 \%$ of the study areas, and were used infrequently by sage-grouse. Elsewhere it has been shown that when juniper cover exceeds $5 \%$ of an area, the likelihood of use decreases (Doherty et al. 2008, Freese 2009).

Because sagebrush availability varied across the elevational gradient in our study, we predicted that big sagebrush communities would be selected at lower elevations and that low sagebrush would be selected at higher elevations.
Contrary to our predictions, there were considerable differences in the use of low and mixed sagebrush habitat types among the study areas. There was lower survival of sage-grouse on the HMNAR and Jack Creek areas during the severe winter of 1990-1991 (Anthony and Willis 2009), but we were unable to link any aspects of habitat selection to these reduced levels of survival.

Vegetation availability and use were more diverse on the Jordan Valley area compared to the 2 other study areas, a situation that poses additional challenges for land managers. Not only do each of these vegetation types respond differently to disturbance (e.g., fire, grazing), they may be predisposed to changes in land use based on topographic location (e.g., exurban development, renewable energy generation). Conservation of tall sagebrush habitats is important for sage-grouse use during all seasons of the year (Connelly et al. 2000), but many of the low sagebrush types also appear to be important during winter in southeastern Oregon. Low sagebrush is often found along higherelevation slopes that are cleared of snow by prevailing winds. Some of these areas have high potential for wind-energy developments, the impacts of which have yet to be determined for sage-grouse populations (Hagen 2011). Impacts that lead to the loss or fragmentation of winter habitats have been detrimental to sagegrouse (Swenson et al. 1987). Our estimates of shrub cover and height in low sagebrush habitats are lower than those suggested in the established Conservation Guidelines (Connelly et al. 2000); however, our data do not refute the guidelines but improve upon them with regionally relevant information. Lastly, we suspect that these low sagebrush types are important foraging areas, but more information on winter diets (see Thacker 2010) of sage-grouse is needed to confirm this speculation. These habitats may be important for other parts of sage-grouse life history (Gregg et al. 1993, Drut et al. 1994).

\section{ACKNOWLEDGMENTS}

Research was funded by the Oregon Department of Fish and Wildlife. We thank T. Thornton, D. Budeau, and 2 anonymous reviewers for constructive comments on earlier drafts of this manuscript; their input has improved the quality of this work. 


\section{Literature Cited}

AMSTRUP, S.C. 1980. A radio-collar for game birds. Journal of Wildlife Management 44:214-217.

ANThony, R.G., AND M.J. Willis. 2009. Survival rates of female Greater Sage-Grouse in autumn and winter in southeastern Oregon. Journal of Wildlife Management 73:538-545.

BatTAZZO, A. 2007. Winter habitat use and survival by Greater Sage-Grouse (Centrocercus urophasianus) in south Philips County, Montana 2004-2006. Master's thesis, University of Montana, Missoula, MT.

BECK, T.D.I. 1977. Sage grouse flock characteristics and habitat selection in winter. Journal of Wildlife Management 41:18-26.

Braun, C.E. 1998. Sage grouse declines in western North America: what are the problems? Proceedings of the Western Association of Fish and Wildlife Agencies 78:139-156.

Canfield, R.H. 1941. Application of the line interception method in sampling of range vegetation. Journal of Forestry 39:386-394.

ConnelLy, J.W., AND C.E. Braun. 1997. Long-term changes in sage grouse Centrocercus urophasianus populations in western North America. Wildlife Biology 3/4:123-128.

Connelly, J.W., M.A. Schroeder, A.R. Sands, and C.E. BRAUN. 2000. Guidelines to manage sage grouse and their habitats. Wildlife Society Bulletin 28:967-985.

Dalke, P.D., D.B. Pyrah, D.C. Stanton, J.E. Crawford, AND E.R. SChlatterer. 1963. Ecology, productivity, and management of sage grouse in Idaho. Journal of Wildlife Management 27:810-841.

Doherty, K.E., D.E. Naugle, B.L. Walker, and J.M. Graham. 2008. Greater Sage-Grouse winter habitat selection and energy development. Journal of Wildlife Management 72:187-195.

Drut, M.S., J.A. Crawford, and M.A. Gregg. 1994. Brood habitat use by sage grouse in Oregon. Great Basin Naturalist 54:170-176.

ENG, R.L., AND P. SChLADWEILER. 1972. Sage grouse winter movements and habitat use in central Montana. Journal of Wildlife Management 36:141-146.

FreESE, M.T. 2009. Linking Greater Sage-Grouse habitat use and suitability across spatio-temporal scales in Central Oregon. Master's thesis, Oregon State University, Corvallis, OR.

Giesen, K.M., T.J. Schoenburg, and C.E. Braun. 1982. Methods for trapping sage-grouse in Colorado. Wildlife Society Bulletin 10:224-231.

GregG, M.A., J.A. Crawford, and M.S. Drut. 1993. Summer habitat use and selection by female sage grouse (Centrocercus urophasianus) in Oregon. Great Basin Naturalist 53:293-298.

Hagen, C.A. 2011. Greater Sage-Grouse conservation assessment and strategy: a plan to maintain and enhance populations and habitat. Oregon Department of Fish and Wildlife, Salem, OR.

Hagen, C.A., J.W. Connelly, and M.A. Schroeder. 2007. A meta-analysis of Greater Sage-Grouse Centrocercus urophasianus nesting and brood-rearing habitats. Wildlife Biology (Supplement 1):42-50.

Hanf, J.M., P.A. Schmidt, and E.B. Groshens. 1994. Sage grouse in the high desert of central Oregon results of a study, 1988-1993. U.S. Department of the Interior, Bureau of Land Management, Portland, OR.
Heady, H.F., and J. Bartolome. 1977. The Vale rangeland rehabilitation program: the desert repaired in southeastern Oregon. Pacific Northwest Forest and Range Experiment Station, U.S. Department of Agriculture, Portland, OR.

Hosmer, D.W., JR., And S. Lemeshow. 1989. Applied logistic regression. John Wiley \& Sons, New York, NY.

Hupp, J.W., AND C.E. BRaun. 1989. Topographic distribution of sage grouse foraging in winter. Journal of Wildlife Management 53:823-829.

KNICK, S.T., AND S.E. HaNSER. 2011. Connecting patterns and process in Greater Sage-Grouse populations and sagebrush landscapes. Pages 383-406 in S.T. Knick and J.W. Connelly, editors, Greater Sage-Grouse: ecology and conservation of a landscape species and its habitat. Studies in Avian Biology 38. University of California Press, Berkeley, CA.

Manly, B.F.J., L.L. MacDonald, D.L. Thomas, T.L. MCDONALD, AND W.P. ERICKSON. 2002. Resource selection by animals: statistical design and analysis for field studies. 2nd edition. Kluwer Academic Publishers, London, United Kingdom.

Moynahan, B.J., M.S. LindberG, and J.W. Thomas. 2006. Factors contributing to process variance in annual survival of female Greater Sage-Grouse in north central Montana. Ecological Applications 16:1529-1538.

Remington, T.E., and C.E. Braun. 1985. Sage grouse food selection in winter, North Park, Colorado. Journal of Wildlife Management 49:1055-1061.

RoberTSOn, M.D. 1991. Winter ecology of migratory sage grouse and associated effects of prescribed fire in southeastern Idaho. Master's thesis, University of Idaho, Moscow, ID.

RosenberG, D.K., and K.S. McKelvey. 1999. Estimation of habitat selection for central-place foraging animals. Journal of Wildlife Management 63:1028-1038.

Schroeder, M.A., C.L. Aldridge, A.D. Apa, J.R. Bohne, C.E. Braun, S.D. Bunnell, J.W. Connelly, P. DieBert, S.C. Gardner, M.A. Hilliard, et aL. 2004. Distribution of sage-grouse in North America. Condor 106:363-376.

Shtatland, E.S., S. Moore, and M.B. Barton. 2000 Why we need $\mathrm{R}^{2}$ measure of fit (and not only one) in PROC LOGISTIC and PROC GENMOD. Pages 1338-1343 in SUGI 2000 Proceedings. SAS Institute, Cary, NC.

Swenson, J.E., C.A. Simmons, and C.D. Eustace. 1987. Decrease of sage grouse Centrocercus urophasianus after ploughing of sagebrush steppe. Biological Conservation 41:125-132.

Thacker, E.T. 2010. Greater Sage-Grouse seasonal ecology and responses to habitat manipulations in northern Utah. Doctoral dissertation, Utah State University, Logan, UT.

Wallestad, R.O., J.G. Peterson, and R.I. Eng. 1975. Foods of adult sage grouse in central Montana. Journal of Wildlife Management 39:314-319.

Wisdom, M.J., M.M. Rowland, B.C. Wales, M.A. HemStrom, W.J. Hann, M.G. RaphaEl, S. Holthausen, R.A. Gravenmier, and T.D. Rich. 2002. Modeled effects of sagebrush steppe restoration on Greater Sage-Grouse in the Interior Columbia Basin, USA. Conservation Biology 16:1223-1231.

Received 20 September 2010 Accepted 8 August 2011 